\title{
Solidarity and social behaviour: how did this help communities to manage COVID-19 pandemic?
}

\author{
Paul Agu Igwe, Chinedu Ochinanwata, Nonso Ochinanwata, \\ Jonathan Olufemi Adeyeye, Isaac Monday Ikpor, \\ Sanita Ekwutosi Nwakpu, Obiamaka P. Egbo, Ike E. Onyishi, \\ Olusegun Vincent, Kenneth Chukwuma Nwekpa, \\ Kingsley Onuoha Nwakpu, Ayodeji Adeyinka Adeoye, \\ Precious Onyinyechi Odika, Henrietta Fakah, \\ Olaleke Oluseye Ogunnaike and Evelyn Iyose Umemezia \\ (Information about the authors can be found at the end of this article.)
}

\begin{abstract}
Purpose - During the coronavirus (COVID-19) pandemic lockdowns, stay at home or work from home, many have argued that the westernised non-pharmaceutical interventions (NPI) do not provide remedial in lowincome countries like Nigeria, where informal job seekers, street traders, informal labourers and artisans depend mainly on the informal economy. By applying social solidarity (SS) and community-based approach (CBA), the authors evaluate individual acts (trust, altruism and reciprocity) during the lockdown and how these practices evolve from individual approaches to collective actions.

Design/methodology/approach - This study reflects on pragmatism research paradigm that enables researchers to maintain both subjectivity in their reflections and objectivity in data collection and analysis. The authors adopt a qualitative method through purposeful and convenience sampling procedure. Data were analysed thematically to identify elements of SS, individual acts, collective or community actions and perceptions.

Findings - The findings reveal that COVID-19 had a disproportionate impact (lack of food and a fall in daily income) on workers, informal job seekers, informal businesses operators and the poor households. As such, the study developed a reflective model of solidarity exhibited by individual acts and collective acts (practices of resource pooling, information sharing, women empowerment, distribution of palliatives and donations) within trusted circles that helped people cope with the lockdown experiences.

Practical implications - Solidarity represents beliefs, practices of values and norms. The SS exhibited by people through NPI would have implications on planning and monitoring the effectiveness of public health programmes during a pandemic in the future.

Social implications - The findings of citizens and community actions have implications related to the process of building communities - coming together - and solidarity that enhances social development with implications on community health policy agenda during disasters, emergencies and health pandemic.

Originality/value - This is one of the first studies to analyse the relationship between trust, altruism, reciprocity, SS and CBA during the COVID-19 pandemic. Also, it seems reasonable to clarify the concept of SS given the lack of clarity about the definitions from previous studies.
\end{abstract}

Keywords Social solidarity, Community-based approach, Community health, COVID-19, Nigeria

Paper type Research paper

\section{Introduction}

Solidarity is not an exogenous analytical concept but a concept inspiring people in contexts of everyday life in crisis (Rakopoulos, 2016). This article examines the contexts and

The authors would like to thank the management of African Development Institute of Research Methodology (ADIRM), Independence Layout, Enugu, Nigeria for sponsoring this research.

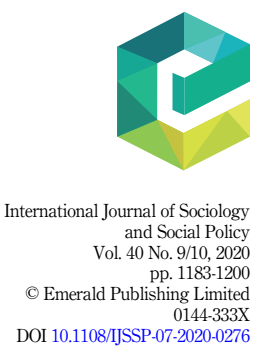

Received 9 July 2020 Revised 20 September 2020 10 October 2020

Accepted 11 October 2020 
IJSSP

$40,9 / 10$

1184 assemblages of social solidarity (SS) and community-based approach (CBA) during the COVID-19 outbreak originating from China that spread rapidly throughout the world, forcing many countries to close their borders, put travel restrictions and ordered their citizens to stay at home or work from home (Gössling et al., 2020; Nicola et al., 2020; Weible et al., 2020). Many dominant approaches see a crisis as a liminal stage of uncertainty between periods of normality (Rakopoulos, 2016). Previous studies stress that social heterogeneities provide resources that communities can mobilise to adapt and sustain themselves in response to disruptions (Leap and Thompson, 2018). Hence, previous studies examined the formation of the behavioural correlates of solidarity, such as expectations of receiving support from others (Lindenberg, 1998; Lindenberg et al., 2006, cited in Bianchi et al., 2020).

Durkheim (1947, cited in Evans and Evans, 1977) asserts that social solidarity network (SSN) was the ensemble of beliefs and sentiments that are common to average members of the society. Solidarity practices are at once specific to crisis and austerity and an issue with a sociocultural history (Rakopoulos, 2016). The theory of SSN is often employed to describe the complex sets of social relationships in the community, sociological and psychological contexts (Josserand et al., 2017; Smith, 2009). Although most research in social and personality psychology tend to focus on individuals, those individuals are embedded in larger social networks that in turn shape the behaviours of the individuals (Clifton and Webster, 2017). COVID-19 pandemic has unprecedented impacts on health, business and people's livelihoods (Weible et al., 2020). With the limited medical capacity to treat the disease, nonpharmaceutical interventions (NPI) (such as ban on travel or movement of people) were the main strategies to contain the pandemic (Gössling et al., 2020).

During the peak of the pandemic, Nigerian like many other African countries enforced the westernised social distancing and stay-at-home or work-from-home orders. It was suggested that prolonged lockdown in developing countries, represents a trade-off not between saving lives and saving the economy, but between saving some lives from COVID-19 and potentially condemning far more people to hardship or death by other means (World Bank, 2020). In Nigeria, there were little income supports, social benefit and business support packages from the government. During the lockdown, most of the citizens were subjected to the hardship associated with food insecurity, joblessness and poverty (Vincent, 2020; Punch, 2020a, b). Therefore, this article examines how SS and community approaches helped people and communities to cope with COVID-19 lockdowns. Despite the centrality of "community" in disaster research, it has variable meanings and measures and "communities" reflect the reality that most disasters occur in specific geographic localities and usually affect populations in proximity to its epicentre (Kirschenbaum, 2004).

African countries evolving social policies demonstrate the importance of SS to economic, health, disaster and human rights approaches. The critical research questions focus on examining SS and collective behaviours or the lack of it. We evaluate the concepts of trust, altruism and reciprocity and how these concepts evolve from individual approaches to collective actions. Also, we analysed the notion of trust (whether people can rely on one another to mitigate and cope with the lockdown), if people would help someone without expecting a favour in return and citizens' willingness to return favours or the lack of it. Kirschenbaum (2004) developed the notion of "disaster communities" by proposing three tiers based on family-kin, micro-neighbourhood and macro-neighbourhood. Communities are "place-based" and develop through locally oriented interactions of the residents (Kirschenbaum, 2004) and SS serves as a "tool" for analysing social relationships (Smith, 2009).

Lindenberg (1998) and Lindenberg et al. (2006) identified five patterns of "solidarity behaviour" that defined the level of solidarity observable in a social group: co-operation in social dilemmas, fairness in resource sharing, support to others in need, avoiding breach temptations and considerateness in mishap situations. Since the COVID-19 pandemic, health- 
related research has grown rapidly to understand its key trends and challenges. However, only limited studies focused on SS or social network analysis (SNA). This article is intended to contribute to the COVID-19 literature, sociological and psychological contexts as well as exploring the meaning of SS.

The article is organised as follows. The next section reviews the concept of solidarity, a distinguishing feature of SSN and SNA. This is followed by an examination of the concepts of $\mathrm{CBA}$ and disaster communities. The next section explains the Nigerian context and challenges. This is followed by the methodology, findings and discussions and conclusion.

SS and CBA for evaluating lockdown behaviour

\section{Social solidarity network (SSN)}

Social psychological research examines the link between trust and sentiments of solidarity (Molm, 2003; Molm et al., 2007; Lindenberg et al., 2006). Social life entails solidarity, which entails altruism (Offer, 2019). SSN describe social relationships and conceive of individuals as social actors. Also, it emphasises the social-justice, socio-political and socio-economic dimensions of such relationships (Smith, 2009). Both etymologically and in colloquial usage, solidarity refers to the sense of responsibility or, rather, mutual responsibility (Buzek and Surdej, 2012). Because social networks represent relationships (ties) among people (nodes) in groups, they become of interest to both social and personality psychologists (Clifton and Webster, 2017).

A key distinguishing feature of SSN and SNA is their focus on the study of not only individual behaviours, attitudes or beliefs, but on the relationships that exist among social actors and the patterns or implications of these interactions (Smith, 2009). Since the outbreak of COVID-19, communities and informal groups have sprung into action; people have been connecting and looking out for each other more than usual. Solidarity was felt in cities, urban and local communities across the world as people came together to help each other, volunteer to work in hospitals, community hubs and local charities. For instance, in the United Kingdom, three in four adults thought people are doing more to help others since the pandemic, and nearly two in three adults had checked in on neighbours who might need help (Public Health England, 2020).

Solidarity often acts as a conceptual bridge between stakeholders and actors. Therefore, SSN involves individual and collective actions (Figure 1). Within the individual actions are elements of trust, altruism and reciprocity. Trust and shared values increase feelings of selfesteem and security within and between communities (Douwes et al., 2018). Altruism reflects an unselfish behaviours and desire to live for others and placing what is good for others above what is good for oneself (Douwes et al., 2018). According to Bianchi et al. (2020) studies on unequal-power networks have found that this link depends on the generation of trust between partners. Bianchi et al. (2020) note that trust is affected by the presence of agreements to protect partners from mutually exploiting each other. Agreements would not allow partners to learn each other's trustworthiness or prevent partners from developing trust relationships and eventually hinder the emergence of solidarity (Bianchi et al., 2020).

Solidarity according to Durkheim (1947, cited in Evans and Evans, 1977, p. 34), solidarity represents shared beliefs (sentiments) and practices which involved both acting and feeling guided by set values and common norms of behaviour. Religion was a unified system of beliefs and practices that were relative to sacred things according to Durkheim. SNA provides researchers with a multiparadigm perspective and how to conceptualise informal social networks in organisations (Kilduff and Tsai, 2003). Borgatti et al. (2013) described the various research design and data collection in social network research. In this article, the focus is not SNA but on SS. However, it appears that sociologists often disagree about definitions of SS; hence it seems reasonable to clarify the concept (Evans and Evans, 1977). Therefore, we reviewed previous definitions (as presented in Table 1). 
IJSSP

$40,9 / 10$

\section{6}

Figure 1.

Conceptual framework of social solidarity and collective action

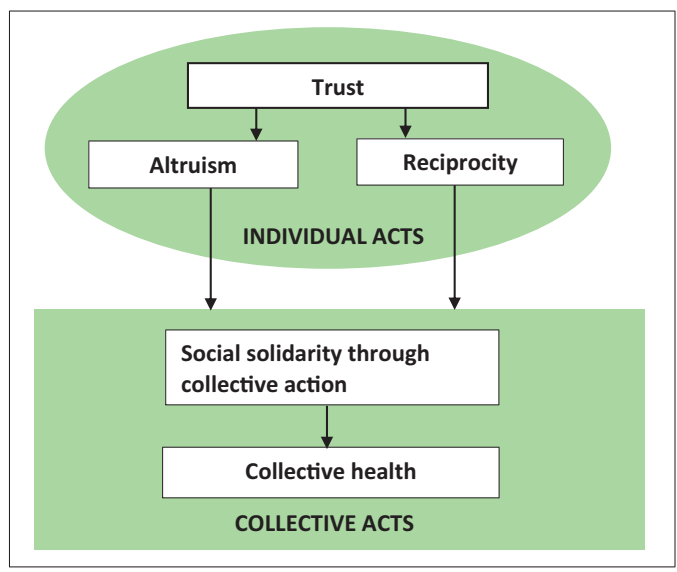

Source(s): Douwes, Stuttaford \& London (2018)

\begin{tabular}{|c|c|c|}
\hline Authors & Definitions & Elements of solidarity \\
\hline Young (1968) & $\begin{array}{l}\text { The degree to which the meaning areas maintained by a } \\
\text { community manifested a unified or coordinated configuration }\end{array}$ & $\begin{array}{l}\text { Unification and } \\
\text { coordination }\end{array}$ \\
\hline Moxley (1973) & $\begin{array}{l}\text { Represents consensus, symbiotic, collectivities, cohesiveness, } \\
\text { interdependence and moral integration as well as integration }\end{array}$ & Collectiveness \\
\hline Moxley (1973) & $\begin{array}{l}\text { The tendency of a system to process all incoming and outgoing } \\
\text { information according to one integrated format; or more concretely, } \\
\text { it is the degree to which the meaning sectors of a symbolic } \\
\text { structure, no matter how differentiated, show overall unity }\end{array}$ & Symbolic structure \\
\hline Wilde (2007) & $\begin{array}{l}\text { The feeling of reciprocal sympathy and responsibility among } \\
\text { members of a group which promotes mutual support }\end{array}$ & Mutual support \\
\hline Adair (2008) & $\begin{array}{l}\text { Shared commitments to social practices; social regulation is direct } \\
\text { and externalised control over such practices is via law and custom }\end{array}$ & Shared commitments \\
\hline $\begin{array}{l}\text { Douwes et al. } \\
\text { (2018) }\end{array}$ & $\begin{array}{l}\text { Solidarity is an element of human association that emphasises the } \\
\text { cohesive social bond that holds a group together, which is valued } \\
\text { and understood by all group members }\end{array}$ & Social bond \\
\hline \multicolumn{3}{|c|}{ Note(s): Complied by the Authors } \\
\hline
\end{tabular}

Table 1.

Review of literature on definitions of Solidarity
The relationship between SS and community solidarity (CS) highlights two issues: first, how SS practices and paradigms overlap with community development and second, how SS brought communities together which allows citizens to form a risk-adjusted strategy on COVID-19 prevention and containment measures. Therefore, this article stresses connectedness, looking at the configurations of activities laying citizens claims to solidarity. It focuses on articulating citizens' experiences, individual behaviours and collective actions during the COVID-19 pandemic.

Roblain et al. (2020) maintain that solidarity actions can take different forms, such as volunteerism, donating to the disadvantaged, political activism or collective actions. Meaning arises in the process of interaction between people and involves a sense of "we-ness" (Evans and Evans, 1977, p. 40). Roblain et al. (2020) argued that the two broad forms of solidaritybased actions can be distinguished as benevolent support and activist support. Benevolence aims at alleviating the suffering of people in need while activism, aims at changing the socio- 
political system (Roblain et al., 2020). Consequently, SS and CBA are gaining prominence in healthcare research (Lavery, 2018; Pratt et al., 2020).

\section{Community-based approaches (CBA)}

The term CBA has a wide range of meanings (McLeroy et al., 2003). CBA has been developed with the aims of redefining and transforming local communities. CBA refers to multicomponent interventions that generally combine individual and environmental change strategies across multiple settings aiming to prevent dysfunction and to promote well-being among population groups in a defined local community (Economos and Hennessy, 2011). Interventions may be citywide, using mass media or other approaches, or may take place within community institutions, such as neighbourhoods, schools, churches, worksites, voluntary agencies or other organisations (McLeroy et al., 2003). In most cases, entire communities are used as units of intervention.

The term community is seldom defined and can be understood in many ways (Räsänen et al., 2020). Kirschenbaum (2004) explains that certain general rules have applied in trying to define disaster communities. Disaster community can be applied to examine the interactionbased community of informal social networks. In general, these have been viewed primarily in terms of their physical and geographic boundaries. There is never a clear demarcation of the dispersion of the social networks linked to the disaster area (Kirschenbaum, 2004). CBA is popular in promoting public health policies and research. As a setting, the community is primarily defined geographically and is the location in which interventions are implemented (McLeroy et al., 2003). Targeting population groups at high risk may be a more feasible approach in terms of interventional costs as well as in measuring the outcome of such an initiative (Economos and Hennessy, 2011). Various levels of intervention may be employed, including educational or other strategies that involve individuals, families, social networks, organisations and public policy (McLeroy et al., 2003).

Räsänen et al. (2020) identify three dimensions: ecological (space and time), social structural (networks and interactions) and symbolic cultural (identities, norms and values). The first conceptualisation of community refers to the community as a (small) spatially defined entity or the totality of individuals and social structures within a specific geographical location (Räsänen et al., 2020). The focus is a specific place, typically a village or a residential area and the community. The second conceptualisation CS refers to the interaction-based community (i.e. interactions between people) (Räsänen et al., 2020). The interaction-based community is tightly connected to the concept of social capital, which can be divided into strong social networks (bonding capital), weaker social networks (bridging capital) and linkages between power and citizens (linking capital) (Räsänen et al., 2020). The foci in this understanding are informal co-operation and everyday life of the inhabitants of the specific community (Räsänen et al., 2020).

The third conceptualisation refers to a community of practice and interest (i.e. specialised networks of actors who share a practice they perform together). These actors engage in common actions and share an (imagined) identity and align activities towards a shared goal, shared interest, which promotes collaborative behaviour in the group (Räsänen et al., 2020). These informal communities organise themselves and actors within them can include authorities, civil society organisations and community residents (Räsänen et al., 2020).

Finally, another form of CBA is the community as an agent which emphasises respecting and reinforcing the natural adaptive, supportive and developmental capacities of communities (McLeroy et al., 2003). COVID-19 underscores the urgency of holistic CBAs to health, hygiene, food insecurity and poverty. CBA is essential for health and wellbeing as it promotes the value of social connections, neighbourliness, sense of belonging, consultation, control and mutual trust. Consultation with the community (listening to the people, getting evaluating lockdown

behaviour

1187 
IJSSP

$40,9 / 10$

inputs from them, understanding their concerns and all leaders joining hands, working together to defeat this virus is doing is very, very important, according to World Health Organisation Director (see, e.g. Mbewa, 2020).

\section{The Nigeria context and challenges}

Social solidarity stresses the interdependence between individuals in a community, which allows individuals to feel that they can enhance the lives of others (Douwes et al., 2018). In the wake of global responses to the COVID-19 pandemic, the Nigerian government followed global practices by imposing lockdown and containment measures - stay at home order. The questions many policymakers and international development agencies ask is how we can reconcile these measures with poverty-environment, harsh economic and informal economy dependent low-income countries like Nigeria. Many have argued that the westernised approach does not provide remedial in an environment of informal job seekers, street traders, informal labourers and artisans who depend on the informal economy that is based on daily wages (Punch, 2020a). About 9 in 10 rural and urban workers in Africa depend on the informal sector for daily income and wages (Vincent, 2020; African Development Bank AfDB, 2013).

One would be forgiven for thinking Nigerians swim in richness, but no, majority of the population lack access to necessities such as food, clean water, electricity, basic healthcare, basic education, etc. The past governments failed to provide adequate medical facilities or add new health facilities. According to a report by BBC Africa (2020), Nigerians spent more than 1 billion naira (about $\$ 800 \mathrm{~m}$ ) on treatment in overseas hospitals in 2013. Economically, Nigeria has become the poverty capital of the world by overcoming India (World Economic Forum, 2019). According to the World Economic Forum (WEF, 2019), African highest oil producer in the world and one of the largest populations of youth in the world has about 90 million people-roughly half its population-living in extreme poverty (those living on less than $\$ 1.90$ per day) and unemployment among the working-age group has hit $23.1 \%$.

COVID-19 lockdown only exacerbated the poverty problem. According to the World Bank, the attributes of poverty and institutional void include poor access to credit, poor health and education facilities, poor access to information, high-interest rates on borrowing, lack of insurance, high rates of unemployment and over-dependent on informal and low productive sectors. This situation is not only peculiar to Nigeria but 14 out of 18 countries where poverty is rising are in Africa and the forecast is that if current rates persist, $90 \%$ of the world's poorest will be living on the continent by 2030 (WEF, 2019).

Corruption is so pervasive in Nigeria that it has turned public service for many into a kind of criminal enterprise (Human Right Watch, 2011). Nigeria is rank 146 of the least corrupt nation out of 180 countries according to the Corruption Perceptions Index reported by Transparency International (Transparency International, 2019). It is estimated that over $\$ 400$ billion of the Nigerian oil revenue has either been stolen or misappropriated since Nigeria gained independence in 1960 (Okoye, 2012). Corruption in Nigeria is responsible for all kinds of woes, such as abandoned public projects, poor quality of implemented projects, nepotism, insecurity, high rate of poverty and high rate of unemployment (Ijewereme, 2015).

\section{Research method}

Methodological coherence describes the "congruence between the researcher's epistemological and ontological viewpoint, theoretical position/perspective, the methods, and so on" (Poucher et al., 2020). This article is derived from the qualitative research method (Schoonenboom and Johnson, 2017). Qualitative research is an iterative process in which improved understanding to the scientific community is achieved by making new significant 
distinctions resulting from getting closer to the phenomenon studied (Aspers and Corte, 2019). Poucher et al. (2020, p. 164) maintains that "determination of a methodologically coherent study rests on the understanding that the various elements of a qualitative study (e.g., research question, methods, methodology, presentation of results) are aligned with the philosophical assumptions underpinning the research".

SS and CBA for evaluating lockdown behaviour

Data collection process

Due to the lockdown and stay at home order during the peak of the COVID-19 pandemic, we 1189 designed semi-structured questions and used telephone interviews (narrative approach) to explore the research questions. A purposeful and convenience sampling procedure (Suri, 2011) was used to identify and select community leaders, town union leaders and Church leaders identified through Facebook in the South-eastern and South-South regions of Nigeria. We sent the link requesting for volunteers to participate in the study to the community leaders and solicited that they send it to youth leaders, notably business owners, religious leaders, community leaders, senior public servants and social media influencers in their towns, cities and villages.

A total of 98 persons responded to the request. The online link had an option that asked for volunteers to participate in a telephone interview. Of the 98 persons that completed the online link, 39 persons (about $39.79 \%$ ) volunteered to participate in the study by providing their phone numbers. The 39 persons were contacted and interviewed. The adoption of a narrative approach in this research is methodologically consistent with an ontological and epistemological position that considers society made of meaningful actions and interpretation as the principal mode of enquiry (Antonazzo, 2019).

The main themes of the research questions focused on people experiences during the lockdown, individual behaviours, the solidarity and collective actions that developed in the society. This study used open-ended questions that allow the researchers to encourage the participants to elaborate on the phenomenon (Pratono et al., 2020). To encourage participants to share their experiences and elaborate the phenomena from their point of view, the interviews were flexible and carefully adapted to the context (Pratono, 2019). The interviews lasted between 20-30 min. Interviews were recorded, transcribed and analysed thematically to identify themes and sub-themes from the data. Throughout the study, we followed and observed the social-distancing measures and COVID-19 rules in Nigeria by not engaging faceto-face interviews or travelling to meet respondents.

Also, we followed the ethical procedures by informing participants about the aim and objectives of the study. Consent was obtained from the participants before the interviews proceeded, they were informed that they can withdraw at any time or choose not to answer any questions if they wished. They were informed that the telephone interviews were being recorded and promised anonymity, hence no personal information was generated that will enable the identification of participants. Of the 39 persons that were interviewed, 15 were women and 24 men with ages between 23 and 56 years. Also, 28 persons were self-employed, while only 11 were engaged in regular wage-employment.

\section{Data analysis and coding process}

All the interview data were entered in a Microsoft Excel spreadsheet composed of multiple tabs. The thematic analysis helps to identify dominant themes that best fit the research questions (Guest et al., 2012). Also, coding and recoding of emergent themes were performed to help extract meaning from the data (Blair, 2015). Vollstedt and Rezat (2019) describe three kinds of coding procedures: open, axial and selective coding. Coding was undertaken through Excel. The first step of coding (open coding), the data are coded into general themes by assigning a word or phrase to each category (Igwe et al., 2018). In the second step, axial 
IJSSP

$40,9 / 10$

1190

coding, data are put back together in new ways by making connections between themes. The coding was conducted by members of the research team. Coders identified responses (categories) related to the research questions.

Open coding is the part of data analysis that focuses on the conceptualisation and categorisation of phenomena through an intensive analysis of the data (Vollstedt and Rezat, 2019). Open coding enables researchers to familiarise themselves with each case as a standalone entity and allows unique patterns to emerge before attempting to identify cross-case patterns (García and Welter, 2011). Axial coding was undertaken to determine the categories of data and dimensions of categories. In the third step, selective coding, a core category is selected with the goal of interpreting them (Igwe et al., 2018). The emerging relationships between the elaborated concepts need to be integrated into an overarching framework with one core category (Vollstedt and Rezat, 2019).

\section{Findings and discussion}

The themes that emerged from the qualitative data include (1) SS and community action; and (2) perception and people experiences of the lockdown.

\section{Social solidarity and community action}

Solidarity is an element of human association that emphasises the cohesive social bond that holds individuals or a group together. SS and CS were evident during the COVID-19 lockdown. We enquired about all types of individual and collective behaviours and solidarity or the lack of it. Under SS, we identified individual acts concerning the concepts of trust, altruism and reciprocity and how these concepts evolve from individual approaches to collective actions or CS (Table 2). We evaluated the notion of trust by asking whether people can rely on one another to mitigate and cope with the lockdown necessitated by COVID-19 pandemic. Concerning altruism, we asked participants if they would help someone without expecting a favour in return during the lockdown. We examined the concept of reciprocity by evaluating participants' willingness to return favours or the lack of it. The findings are presented in Table 2.

Our findings revealed that people in the rural areas trusted on one another more than those in the urban and cities. Also, rural locations had had more interaction-based community that urban and cities. Shared beliefs, cultural norms and religion formed the foundation for SS and CS in rural areas. Like Durkheim findings, religion and cultural values provided a unified system of belief and practices related to individual and collective actions. Nigeria is a religious state and most of the population practices Christianity or Islam. These religions teach "love your neighbours as you love yourself" and "help someone without expecting a favour in return". This was the foundation for moral integration (as stated by Moxley, 1973) and sacred things (highlighted by Durkheim). Hence, participants shared a positive view of altruism and how people looked after each other.

A sense of collective actions and CS was displayed through pooling resources together to help disadvantaged households, contributing to community development or volunteering to join many people-focused initiatives in the absence of government programmes. In their study Douwes et al. (2018) have suggested that self-interest can be a motive for solidarity, however, self-interest must be accompanied by feelings of affection and trust in order for this to be true.

Our finding showed that receiving a favour does not leave one feeling obliged to return it, but there is anticipation that a reciprocal might be required in the future. Reciprocal acts or bonds were found to be more established within families who lived in the cities, while selfless concern (altruism) were more exhibited by rural people. Above all, there was a sense of "weness" among rural communities than the urban and city dwellers. 
Themes

Individual acts

"City dwellers tend to look out only for themselves and their immediate families than look out for strangers. Also, people in the rural areas rely on one another more than those in the urban and cities because it is hard to trust strangers or people that are not in your social or family circle" (Social media influencer)

"Strong ties in the rural areas come from community leaders, business leaders and influential persons in the communities who are change agents that volunteer to solve social or developmental problems" (Religious leader) "Not anymore. People do not trust each other as before. Trust is limited to family members, not with friends or strangers" (Youth leader)

"People have lost hope in government and their agents because politicians have repeatedly lied to the people and make bogus promises they are never kept. Hence, during the lockdown, people never trusted that any assistance will come from the government" (Community leader)

"People trusted in their close friends and families to provide information regarding the pandemic" (Youth Leader)

"You cannot trust nobody. In the urban and cities, people tend to act for themselves or their immediate families because of lack of trust and fear of reciprocity, especially if you're a woman" (Women leader)

"Trust has eluded modern societies. People are afraid to collect gifts or materials from strangers for fear of the unknown such as witchcraft and ritual. Therefore, people relied mostly on their family network or social friends during the lockdown" (NGO coordinator)

"God expects us to do favours out of our heart and not to expect anything back from that person" (Religious leader)

"During the lockdown, individuals and communities were donating food and cash material to women, especially widows and those without stable means of livelihoods" (Community leader)

"Only when it concerns vulnerable or elderly people and about young people who should go and work harder" (Business owner)

"The Bible teaches us to live a selfless life, help and care for each other. That is why the Church was involved in coordinating relief materials during the lockdowns" (Religious leader)

"Solidarity helped to go into local initiatives such as COVID-19 enlightenment, sourcing and distribution of free face masks, etc" (Social media influencer)

"Of course, giving and exchanging favours helps one to expand the social network that will be required in future during social ceremonies, a period of hardship, deaths or sickness" (Business leader)

"Some people help with the mind of asking something in return now or in future, hence, people are hesitant to collect gifts from strangers" (Women leader)

"Nowadays people just focus on themselves and do not think about others because people have been betrayed by the government and politicians" (Women leader)

"The motive for solidarity is that what comes around, goes around, the saying goes [... . . People give because the future is uncertain. You might be rich today, but you never know the future and if you will require help from others" (Religious leader)

\section{Collective Acts}

"We worked together, pooled resources together and distributed essential materials to less privileged households and widows" (Youth leader)
Categories

Trust

Altruism

Reciprocity

Unification and coordination

Table 2 .

Elements of social solidarity and collective action 


\section{IJSSP $40,9 / 10$}

Themes

Individual acts

"People relied on information from social media - Facebook and WhatsApp to get a better understanding about the pandemic and the preventive measures" (Social media influencer)

"Nothing happened in my community. No help and assistance from government or individuals. Everyone had to find ways to survive" (Youth Leader)

"Solidarity actions were lacking in the cities and crime was high and people were afraid, especially at night as people took to crimes due to hardship during the lockdown. This situation led to setting up voluntary vigilante groups and neighbourhood watch" (Senior public servant)

"Lack of government actions formed the basis of social solidarity during the lockdown. They ordered everyone to stay at home but there was no clarity in the information about the pandemic and government plans" (Traditional ruler)

"Everyone came together - civil servants, business owners, traditional leaders and were united together to overcome the challenges of the lockdown" (Youth leader)

"There is mistrust among people and lack of leadership in our community. As a result, people ignored community leaders calls for united initiatives because past community projects lacked accountability and transparency" (Business owner)

"The lockdown provided opportunities for communities to come together and plan about community challenges such as security issues, town planning and community projects" (Community leader)

"The community was united during the lockdown, everyone taking

Table 2.
Categories

Trust

\section{Social bond}

Collectiveness and symbolic structure

Mutual support and shared commitments

\section{People experiences of the lockdown}

CS and SS provide a bridge for public health and social development. Health education has been crucial as many Nigerians live in denial of the devastating reality of the coronavirus (Punch, 2020a). Government measures were described as inadequate and ineffective;

Government measures are defective in several ways from the formulation of COVID-19 containment policies, testing, support and palliative measures. There have not been much to support small-scale businesses and ordinary citizens [Community leader].

Only an insignificant proportion of the population has been supported and the majority have been marginalised and do not know when help will come to them and how [Social media influencer].

People supported one another through the sharing of information about COVID-19 preventive measures and action deemed necessary and proportionate to support the vulnerable people during the lockdowns. From the interviews, it was clear that COVID-19 pandemic disrupted people's livelihoods, with a disproportionate impact on rural and urban households, informal job seekers, street traders, low-income earners and informal businesses operators. The pandemic further highlighted the deep economic and social inequalities and inadequate health and social protection systems in Nigeria;

Ordinary people and vulnerable groups have been subjected from hardship from poverty to the real suffering from lack of income, food deprivation and hunger [NGO coordinator].

Travel bans and lockdowns were not only limiting the movement of people across borders but also disrupted food supply chain, informal jobs, manufacturing, trade, education, social 
and religious activities. According to the World Bank (2020), this situation is particularly acute in developing nations where the majority of the population have extremely limited savings and are especially vulnerable to "economic shutdowns" of any duration.

The lockdown of the economy has affected households negatively. It has devastated people's income and some people find it very difficult to feed their families [Religious leader].

People are saying, poverty and hunger are worse than the main reason for the lockdown [Social media influencer].

According to some national newspaper reports, the lockdown has unleased widespread social insecurity, hunger and economic joblessness (see, e.g. Punch, 2020b). Due to inadequate measures by the government, people engaged in SS and CS. Individuals, families, neighbours and members of the public were connected and looked out for each other more than usual. Also, informal social groups sprung up in many local, urban and cities.

\section{Social solidarity model}

The purpose of theory is to increase scientific understanding by explaining and predicting phenomena (Hunt, 2014). Our research findings suggest that individual and collective actions were pivotal in the dissemination of information concerning the pandemic, distribution of preventive and relief materials to disadvantaged people in the society. Hunt (2014) suggests some factors that substantially explain theory's development. The theory: (1) addresses important issues; (2) exhibits high explanatory and predictive power; (3) respects other disciplines' literatures and (4) has normative implications (Hunt, 2014). SS and CS recognise the needs of human beings to come together to solve the problems they have in common (Buzek and Surdej, 2012; Clifton and Webster, 2017; Mukerji and Chauhan, 2019).

From the findings, it appears that the level of trust varied from rural, urban and cities. Like the findings from Young (1968) rural communities looked out for one another, while city dwellers tend to look out only for close families and friends. Also, individual approaches to collective actions varied from social group and locations (as shown in model Figure 2, adapted from Douwes et al. (2018) but modified to reveal the level of impact). Rural communities were more focused and united in pursuit of community development and helping one another. The lack of trust in the cities meant that people relied mostly on families and close friends than on

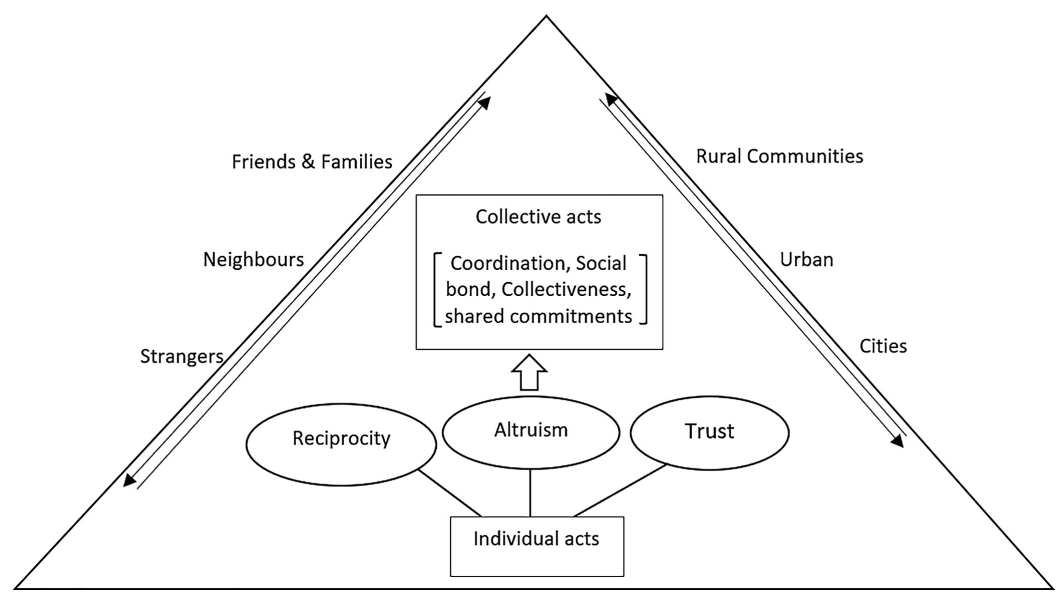

Figure 2. A reflective hierarchical model of social solidarity

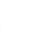


IJSSP

$40,9 / 10$ strangers. Also, a sense of moral integration existed in rural areas than in the cities. Reciprocal acts existed within families and social friends in the urban and cities.

\section{Emergent model}

During the COVID-19 lockdown, solidarity manifested in several ways. Trust in others enabled interactions that helped people deal with the experiences of the COVID-19 lockdown. Likewise, trust shrinks rapidly if one move from rural to urban and cities. Altruism (unselfish behaviours and desire to live for others) dwindles in the urban and cities. Most people also reciprocate the fairness of others during the COVID-19 pandemic. Unfairness is also reciprocated and people who feel mistreated during the pandemic came together to exhibit SS. People willingness to trust and be fair to others during the pandemic was reflected in several ways. Social networks created social bond, norms of reciprocity and trustworthiness and collectiveness during the lockdown.

First, people valued their neighbours and supported vulnerable people in the fight to prevent the spread of COVID-19 pandemic. Second, community support was evident as people came together to plan and execute some community projects, people-focused palliatives (such as relief materials, food, cash and masks). Solidarity in developing countries during COVID-19 pandemic has become critical since government preventive measures and palliative scheme has been inadequate.

To examine the proposed typologies, this study used the criteria based on categorisation (Hunt, 2014). A reflective model of SS (Figure 2) shows the disproportionate SS between rural, urban and cities. Rural communities were bonded together through traditional values and religious beliefs (sentiments) of togetherness and interdependence. Like Fessler (1952) rural communities functioned as a social group which have set values and common norms. There was a strong feeling of social interactions in rural areas than urban centres and cities. There were more tendencies for social distancing and stranger notion in the cities due to fear of unknown and reciprocity. These affected the solidarity expressed towards others in the urban and cities.

\section{Conclusions and implications}

A sense of shared beliefs (sentiments) and mutual self-interest is at the core of SS and communities are motivated by moral values, religion and cultural norms. In this article, we adopted a narrative approach as the ontological and epistemological position that considers subjectivity and objectivity in analysing people's acting and feeling. We examined the degree to which communities maintained a unified or coordinated action towards overcoming the impact of COVID-19 lockdowns. SS enabled the dissemination of vital information concerning preventive measures and coordination of relief materials. SS and CS embody an ethic of social religious and moral responsibility as exhibited in many communities during COVID-19 pandemic. Communities came together to support each other, educate and raise awareness about the disease and support vulnerable groups.

Creating trust and empathy are core element of solidarity. The collectiveness and a sense of "we-ness" that developed among business owners, community leaders, youth leaders, public servants and religion leaders enabled people to overcome some of the hardship imposed by the lockdowns. The spirit of co-operation in solving mutual problems helped people cope with the pandemic hardship. Trust grows with familiarity among families and friends and shrinks rapidly from neighbours to strangers. The spirit of collaboration, collectiveness and cohesiveness enabled actors to be viewed as "Allies" rather than as rivals or competitors. These have implications towards strengthening institutional and community resilience and adaptability during a pandemic. This suggests integrating an SS-type model in future pandemic or disasters. The model exemplifies how members of the society and the community form a symbolic structure to pursue mutual or public interests. 
The bases of solidarity-moral imagination, recognition, understanding, empathy-can be built by community engagement over time (Pratt et al., 2020). The solidarity exhibited by individual behaviours (trust, altruism and reciprocity) and collective action (practices of resource pooling, information sharing, women's empowerment, distribution of palliatives and donations) were analysed in this article. Our findings revealed that a sense of solidarity varied from members of rural, urban and city dwellers. The level of trust, altruism and reciprocity was more in rural than urban and cities. Also, a sense of trust, altruism and reciprocity was felt more among families/friends than neighbours and less among strangers.

One of the main concerns of local, international agencies, activities and non-governmental agencies during the peak of the COVID-19 pandemic was how the lockdown/stay at home order will impact on livelihood, food and general welfare of people in developing countries (like Nigeria) whose majority of the population depend on informal jobs and daily labour. Therefore, not able to go out to work and staying home means losing their jobs and their livelihoods (International Labour Organisation ILO, 2020).

Overall, solidarity - coming together by having shared interest, goals and mutual benefits - enhanced social and community cohesion during the pandemic. In developing countries with limited public resources and revenues, individuals and community support (social capital) are vital resources to have to achieve economic development. There is a high rate of poverty and unemployment in Nigeria. Majority of the population depend on the informal economy like street trading, daily paid work and informal market. COVID-19 exacerbated these conditions and threatens to jeopardise the health, livelihoods, security, education and social and economic development.

The findings and analysis of SS have social, economic and policy implications. Culture and society influence norms. Building trust during the pandemic was of mutual interests and social cohesion. Many individuals, businesses and organisations worked together to build trust, exchange obligations and co-operation. People tend to act altruistically (i.e. people are more likely to help those who need help even if there is no reciprocal). This behaviour varies among individuals and among cultural norms. Solidarity is required for NPI, planning and monitoring the effectiveness of public health programmes during a pandemic in the future. Solidarity enhances social cohesion and community development. Also, solidarity enabled businesses to cope with the challenges (e.g. loss of revenues and supplies) associated with lockdowns, work from home and stay at home. Finally, CS is required in public health, national orientation and developing public goods.

As part of our contributions, this article adds to the literature on COVID-19, SS and community studies. Solidarity is needed to solve future pandemic, disasters and global economic challenges, but what does this entail? In this article, we re-examined the definitions of SS and explored the elements of SS and collective action during the COVID-19 pandemic. Solidarity represents beliefs, practices of values and moral norms. Our findings show that SS enhanced interconnections of people and communities during the COVID-19 pandemic. Solidarity has an organic or ethical category-civic virtues and collective identity. It involves specific social cohesion and mutual integration. In this context, the actor seeks how to help, and actors believe they are obligated to provide help.

Despite the merits of the qualitative research (applied to the social world and the concepts and behaviours of people within it), there are several limitations related to the number of participants, data saturation and the scope of the study. Also, certain factors can affect the subjects' responses and biases (Igwe et al., 2020a, b). The narrative approach recognises that a story is never the whole story since any story is embedded in a context (Gartner, 2007; Igwe Madichie and Amoncar, 2020). Despite the limitations, this article provides the foundation for future studies on CBA, SNA and SS approach to public health and disasters research, especially from a developing country context. 
IJSSP

$40,9 / 10$

1196

\section{References}

Adair, S. (2008), "Status and solidarity: a reformulation of early Durkheimian theory", Sociological Enquiry, Vol. 78 No. 1, pp. 97-120.

African Development Bank, AfDB (2013), "Recognizing Africa's informal sector", 27 March 2013, available at: https://blogs.afdb.org/afdb-championing-inclusive-growth-across-africa/post/ recognizing-africas-informal-sector-11645 (accessed 10 June 2020).

Antonazzo, L. (2019), "Narratives of cooperation, resilience and resistance: workers' self-recovery in times of crisis", International Journal of Sociology and Social Policy, Vol. 39 Nos 9/10, pp. 851-864, doi: 10.1108/IJSSP-04-2019-0064.

Aspers, P. and Corte, U. (2019), "What is qualitative in qualitative research", Qualitative Sociology, Vol. 42 No. 2, pp. 139-160, doi: 10.1007/s11133-019-9413-7.

Bianchi, F., Flache, A. and Squazzoni, F. (2020), "Solidarity in collaboration networks when everyone competes for the strongest partner: a stochastic actor-based simulation model", Journal of Mathematical Sociology, Vol. 44 No. 4, pp. 249-266.

Blair, E. (2015), "A reflexive exploration of two qualitative data coding techniques", Journal of Methods and Measurement in the Social Sciences, Vol. 6 No. 1, pp. 14-29.

Borgatti, S.P., Everett, M.G. and Johnson, J.C. (2013), "Analysing social networks", Journal of Mathematical Sociology, Vol. 39 No. 3, pp. 221-222, doi: 10.1080/0022250X.2015.1053371.

British Broadcasting Service, BBC (2020), "Coronavirus in Africa tracker", 08-07-2020 20:30 GMT, available at: https://www.bbc.co.uk/news/resources/idt-4a11d568-2716-41cf-a15e-7d15079548bc (accessed 24 July 2020).

Buzek, J. and Surdej, A. (2012), "Paradigm lost, paradigm rediscovered? Prospects for the development of solidarity-oriented economy in post-communist Poland", International Journal of Sociology and Social Policy, Vol. 32 Nos 1/2, pp. 56-69, doi: 10.1108/01443331211201761.

Clifton, A. and Webster, G.D. (2017), "An introduction to social network analysis for personality and social psychologists", Social Psychological and Personality Science, Vol. 8 No. 4, pp. 442-453, doi: 10.1177/1948550617709114.

Douwes, R., Stuttaford, M. and London, L. (2018), "Social solidarity, human rights, and collective action: considerations in the implementation of the national health insurance in South Africa", Health and human rights, Vol. 20 No. 2, pp. 185-196.

Durkheim, E. (1947), "The division of labour in society. The free press glencoe", in Evans, A. and Evans, A. (Eds), An Examination of the Concept of Social Solidarity, Mid-American Review of Sociology, 1977, Illinois, Vol. 2, No. 1, pp. 1429-4046.

Economos, C. and Hennessy, E. (2011), Global Perspectives on Childhood Obesity, Encyclopedia of Mental Health, 2nd ed., available at: https://www.sciencedirect.com/topics/medicine-anddentistry/community-based-intervention\#: :text=Community $\% 2$ Dbased $\% 20$ interventions $\%$ 20refer\%20to,in \%20a\%20defined\%20local\%20community (accessed 18 June 2020).

Evans, A. and Evans, A. (1977), "An examination of the concept of social solidarity", Mid-American Review of Sociology, Vol. 2 No. 1, pp. 29-46, available at: http://www.jstor.org/stable/23254926 (accessed 17 September 2020).

Fessler, D.R. (1952), "The development of a scale for measuring community solidarity", Rural Sociology, June, pp. 144-152.

García, M.-C.D. and Welter, F. (2011), "Gender identities and practices: interpreting women entrepreneurs' narratives”, International Small Business Journal, Vol. 31 No. 4, pp. 384-404.

Gartner, W.B. (2007), "Entrepreneurial narrative and science of the imagination”, Journal of Business Venturing, Vol. 22 No. 5, pp. 613-627, doi: 10.1016/j.jbusvent.2006.10.003.

Gössling, S., Scott, D. and Hall, C.M. (2020), "Pandemics, tourism and global change: a rapid assessment of COVID-19”, Journal of Sustainable Tourism. doi: 10.1080/09669582.2020.1758708.

Guest, G., MacQueen, K. and Namey, E. (2012), Applied Thematic Analysis, Sage, London. 
Human Right Watch Organisation (2011), "Corruption on trial? The record of Nigeria's economic and financial crimes commission", available at: https://www.hrw.org/report/2011/08/25/corruptiontrial/record-nigerias-economic-and-financial-crimes-commission (accessed 15 June 2020).

Hunt, S.D. (2014), "Developing successful theories in marketing: insights from resource advantage theory", Academy of Marketing Science, Vol. 1 No. 2, pp. 72-84, doi: 10.1007/s13162-011-0007-0, AMS Rev, No. 1869-814X.

Igwe, P.A., Newbery, R., Amoncar, N., White, G.R.T. and Madichie, N.O. (2018), "Keeping it in the family: exploring Igbo ethnic entrepreneurial behaviour in Nigeria", International Journal of Entrepreneurial Behavior and Research, Vol. 26 No. 1, pp. 34-53, doi: 10.1108/IJEBR-122017-0492.

Igwe, P.A., Madichie, N.O. and Amoncar, N. (2020a), "Transgenerational business legacies and intergenerational succession among the Igbos (Nigeria)", Small Enterprise Research, Vol. 27 No. 2, pp. 165-179, doi: 10.1080/13215906.2020.1751692.

Igwe, P.A., Odunukan, K., Rahman, M., Rugara, D.G. and Ochinanwata, C. (2020b), "How entrepreneurship ecosystem influences the development of frugal innovation and informal entrepreneurship?", Thunderbird International Business Review, Vol. 62 No. 5, pp. 475-488, doi: 10.1002/tie.22157.

Ijewereme, O.B. (2015), "Anatomy of corruption in the Nigerian public sector: theoretical perspectives and some empirical explanations", Sage Open. doi: 10.1177/2158244015581188.

International Labour Organisation ILO (2020), "COVID-19 crisis and the informal economy immediate responses and policy challenges", ILO brief, May 2020, available at: https://www.ilo.org/ wcmsp5/groups/public/—ed_protect/—protrav/—travail/documents/briefingnote/wcms_ 743623.pdf (accessed 20 June 2020).

Josserand, E., Schmitt, A. and Borzillo, S. (2017), "Balancing present needs and future options: how employees leverage social networks with clients", Journal of Business Strategy, Vol. 38 No. 1, pp. 14-21, doi: 10.1108/JBS-01-2016-0003.

Kilduff, M. and Tsai, W. (2003), Social Networks and Organizations, Sage, London.

Kirschenbaum, A. (2004), "Generic sources of disaster communities: a social network approach", International Journal of Sociology and Social Policy, Vol. 24 Nos 10/11, pp. 94-129, doi: 10.1108/ 01443330410791073.

Lavery, J.V. (2018), "Building an evidence base for stakeholder engagement", Science, Vol. 361 No. 6402 , pp. $554-556$.

Leap, B. and Thompson, D. (2018), "Social solidarity, collective identity, resilient communities: two case studies from the rural US And Uruguay", Social Science, Vol. 7 No. 250, pp. 1-19.

Lindenberg, S. (1998), "Solidarity: its micro-foundations and macro-dependence. A framing approach", in Bianchi, F., Flache, A. and Squazzoni, F. (Eds), Solidarity in Collaboration Networks when Everyone Competes for the Strongest Partner: A Stochastic Actor-Based Simulation Model, The Journal of Mathematical Sociology, Vol. 44, No. 4, pp. 249-266, 2020.

Lindenberg, S., Fetchenhauer, D., Flache, A. and Buunk, A.P. (2006), "Solidarity and prosocial behavior. A framing approach", in Bianchi, F., Flache, A. and Squazzoni, F. (Eds), Solidarity in Collaboration Networks when Everyone Competes for the Strongest Partner: A Stochastic ActorBased Simulation Model, the Journal of Mathematical Sociology, Vol. 44, No. 4, pp. 249-266, 2020.

Mbewa, D.O. (2020), "WHO praises South Africa's community-based approach to COVID-19 fight", April 28, 2020, available at: https://africa.cgtn.com/2020/04/28/w-h-o-praises-south-africascommunity-based-approach-to-covid-19-fight/ (accessed 15 June 2020).

McLeroy, K.R., Norton, B.L., Kegler, M.C., Burdine, J.N. and Sumaya, C.V. (2003), "Community-based interventions”, American Journal of Public Health, Vol. 93 No. 4, pp. 529-533, doi: 10.2105/ajph. 93.4.529.

Molm, L.D. (2003), “Theoretical comparisons of forms of exchange”, Sociological Theory, Vol. 21 No. 1, pp. 1-17, doi: 10.1111/1467-9558.00171. 
IJSSP $40,9 / 10$

Molm, L.D., Collett, J.L. and Schaefer, D.R. (2007), "Building solidarity through generalized exchange: a theory of reciprocity", American Journal of Sociology, Vol. 113 No. 1, pp. 205-242, doi: 10.1086/ 517900 .

Moxley, R.L. (1973), "Social solidarity, ethnic rigidity, and differentiation in Latin American communities", Rural Sociology, Vol. 38 No. 4, pp. 432-468.

Mukerji, M. and Chauhan, U. (2019), "A social network analysis of ICTD conferences, (2006-2017)”, Information Technology for Development, Vol. 26 No. 4, pp. 788-810, doi: 10.1080/02681102.2019. 1685930.

Nicola, M., Alsafi, Z., Sohrabi, C., Kerwan, A., Al-Jabir, A., Iosifidis, C., Agha, M. and Agha, R. (2020), "The socio-economic implications of the coronavirus pandemic (COVID-19) A review", International Journal of Surgery (London, England), Vol. 78, pp. 185-193, Advance online publication, doi: 10.1016/j.ijsu.2020.04.018.

Offer, J. (2019), "Social solidarity and herbert spencer: not the oxymoron that might Be assumed", Frontiers in Sociology, Vol. 4 No. 1, pp. 1-11, doi: 10.3389/fsoc.2019.00001.

Okoye, R. (2012), "Nigeria has lost \$400bn oil revenue to corruption since independence - Ezekwesili", August 31, 2012, Daily Post Newspaper, available at: https://dailypost.ng/2012/08/31/nigerialost-400bn-oil-revenue-corruption-since-independence-ezekwesili/ (accessed 20 June 2020).

Poucher, Z.A., Tamminen, K.A., Caron, J.G. and Sweet, S.N. (2020), "Thinking through and designing qualitative research studies: a focused mapping review of 30 years of qualitative research in sport psychology”, International Review of Sport and Exercise Psychology, Vol. 13 No. 1, pp. 163-186, doi: 10.1080/1750984X.2019.1656276.

Pratono, A.H. (2019), "Cross-cultural collaboration for inclusive global value chain: a case study of rattan industry", International Journal of Emerging Markets. doi: 10.1108/IJOEM-01-2017-0028.

Pratono, A.H., Prima, D.A., Sinaga, N.F.N.T., Permatasari, A., Ariani, M. and Han, L. (2020), "Crowdfunding in digital humanities: some evidence from Indonesian social enterprises", Aslib Journal of Information Management, Vol. 72 No. 2, pp. 287-303, doi: 10.1108/AJIM-05-2019-0123.

Pratt, B., Cheah, P.H. and Marsh, V. (2020), "Solidarity and community engagement in global health research", The American Journal of Bioethics, Vol. 20 No. 5, pp. 43-56, doi: 10.1080/15265161. 2020.1745930 .

Public Health England (2020), "The community response to coronavirus (COVID-19)", in Stansfield, J., Mapplethorpe, T. and South, J. (Eds), Public Health Matters, Posted on:1 June 2020, available at: https://publichealthmatters.blog.gov.uk/2020/06/01/the-community-response-to-coronaviruscovid-19/ (accessed 10 July 2020).

Punch Newspaper (2020a), “Covidiots and Nigeria's COVID-19 challenge”, 03 July 2020, available at: https://punchng.com/covidiots-and-nigerias-covid-19-challenge/ (accessed 25 July 2020).

Punch Newspaper (2020b), "COVID-19: policy response, fallout and challenges in Nigeria”, 18 June 2020, available at: https://punchng.com/covid-19-policy-responsefallout-and-challenges-innigeria/ (accessed 16 July 2020).

Räsänen, A., Lein, H., Bird, D. and Setten, G. (2020), "Conceptualizing community in disaster risk management”, International Journal of Disaster Risk Reduction, Vol. 45 No. 101485, pp. 1-8, doi: $10.1016 / j . i j d r r .2020 .101485$.

Rakopoulos, T. (2016), "The other side of the crisis: solidarity networks in Greece", Social Anthropology, Vol. 24 No. 2, pp. 142-151.

Roblain, A., Hanioti, M., Paulis, E., Van Haute, E. and Green, E.G.T. (2020), "The social network of solidarity with migrants: the role of perceived injunctive norms on intergroup helping behaviors", European Journal of Social Psychology, Vol. 2020 No. 00, pp. 1-12, doi: 10.1002/ejsp.2700.

Schoonenboom, J. and Johnson, R.B. (2017), "How to construct a mixed methods research design", Kolner Zeitschrift fur Soziologie und Sozialpsychologie, Vol. 69 No. 2, pp. 107-131, doi: 10.1007/ s11577-017-0454-1. 
Smith, J. (2009), "Solidarity networks: what are they? And why should we care?", The Learning Organization, Vol. 16 No. 6, pp. 460-468, doi: 10.1108/09696470910993936.

Suri, H. (2011), "Purposeful sampling in qualitative research synthesis", Qualitative Research Journal, Vol. 11 No. 2, pp. 63-75.

Transparency International (2019), "Corruption indices, Nigeria”, available at https://www. transparency.org/en/countries/nigeria (accessed 10 June 2020).

Vincent, O. (2020), “Covid-19: compelling case for withdrawal from employees' RSA”, 5 May 2020, available at: https://businessday.ng/opinion/article/covid-19-compelling-case-for-withdrawalfrom-employees-rsa/ (accessed 25 July 2020).

Vollstedt, M. and Rezat, S. (2019), "An introduction to grounded theory with a special focus on axial coding and the coding paradigm", in Kaiser, G. and Presmeg, N. (Eds), Compendium for Early Career Researchers in Mathematics Education. ICME-13 Monographs, Springer, Cham, doi: 10.1007/978-3-030-15636-7_4.

World Economic Forum (WEF) (2019), "World economic Forum (2019)", Three things Nigeria must do to end extreme poverty, available at: https://www.weforum.org/agenda/2019/03/90-millionnigerians-live-in-extreme-poverty-here-are-3-ways-to-bring-them-out/\#: :text=About $\% 2090 \%$ 20million \%20people $\% 20 \% 2 \mathrm{D} \% 20$ roughly,the $\% 20$ bottom $\% 20$ of $\% 20$ the $\% 20$ table.

Weible, C.M., Nohrstedt, D., Cairney, P., Carter, D.P., Crow, D.A., Durnová, A.P., Heikkila, T., Ingold, K., McConnell, A. and Stone, D. (2020), "COVID-19 and the policy sciences: initial reactions and perspectives", Policy Sciences, Vol. 2020, doi: 10.1007/s11077-020-09381-4.

Wilde, R. (2007), "The concept of solidarity: emerging from the theoretical shadows?", The British Journal of Politics and International Relations, Vol. 9 No. 1, pp. 171-181.

World Bank (2020) in Francisco Ferreira (Ed.), Is There a Trade-Off between Lives and Incomes in the Response to Covid-19?, March 30, 2020, available at: https://blogs.worldbank.org/ developmenttalk/there-trade-between-lives-and-incomes-response-covid-19 (accessed 18 June 2020).

Young, F. (1968), "Differentiation and solidarity in Agricultural communities", Human Organization, Vol. 27 No. 4, pp. 58-74.

\section{Author affiliations}

Paul Agu Igwe, Lincoln International Business School, University of Lincoln, Lincoln, UK

Chinedu Ochinanwata, Lincoln International Business School, University of Lincoln, Lincoln, UK

Nonso Ochinanwata, Research and Training, African Development Institute of Research Methodology, Enugu, Nigeria

Jonathan Olufemi Adeyeye, Business Administration, Alex Ekwueme Federal University Ndufu-Alike, Abakaliki, Nigeria

Isaac Monday Ikpor, Accountancy, Banking and Finance, Alex Ekwueme Federal University NdufuAlike, Abakaliki, Nigeria

Sanita Ekwutosi Nwakpu, Mass Communication, Alex Ekwueme Federal University Ndufu-Alike, Abakaliki, Nigeria

Obiamaka P. Egbo, Banking and Finance, University of Nigeria, Enugu, Nigeria

Ike E. Onyishi, Psychology, University of Nigeria, Nsukka, Nigeria

Olusegun Vincent, Management and Social Sciences, Pan-Atlantic University, Victoria Island, Nigeria

Kenneth Chukwuma Nwekpa, Business management and Entrepreneurship Studies, Ebonyi State University, Abakaliki, Nigeria

Kingsley Onuoha Nwakpu, Department of Medical Microbiology, Ebonyi State University, Abakaliki, Nigeria 
IJSSP

$40,9 / 10$

1200

Ayodeji Adeyinka Adeoye, Aquaculture and Fisheries Management, Federal University of Agriculture Abeokuta, Abeokuta, Nigeria

Precious Onyinyechi Odika, Geological Sciences, Nnamdi Azikiwe University, Awka, Nigeria

Henrietta Fakah, Management Studies, Plateau State University, Bokkos, Nigeria

Olaleke Oluseye Ogunnaike, Department of Business Management, Covenant University, Ota, Nigeria Evelyn Iyose Umemezia, Business Administration, University of Benin, Benin City, Nigeria

\section{Corresponding author}

Paul Agu Igwe can be contacted at: pigwe@lincoln.ac.uk

For instructions on how to order reprints of this article, please visit our website: www.emeraldgrouppublishing.com/licensing/reprints.htm Or contact us for further details: permissions@emeraldinsight.com 